\title{
IMPLEMENTASI ALGORITMA HORSPOOL PADA APLIKASI TAKSONOMI BERBASIS ANDROID
}

\author{
Fazar Ikhwan Guntara, S.Kom \\ fazarikhwan@gmail.com
}

Ilmu taksonomi sendiri memiliki banyak sekali cabangnya. Salah satunya adalah taksonomi tumbuhan (Plantae), Taksonomi tumbuhan lebih banyak mempelajari aspek sampel-sampel tumbuhan dan pengelompokan. Dalam memahami klasifikasi (taksonomi) dan tata nama ilmiah, alat bantu yang umum digunakan adalah buku pelajaran atau tabel klasifikasi (taksonomi) dan tata nama ilmiah sehingga kurang praktis. Banyak masyarakat, siswa maupun mahasiswa sulit untuk menghafal karena berbahasa latin dan klasifikasi (taksonomi) terdiri dari banyak objek. Jenis dan spesies tumbuhan sangat banyak, sehingga dalam mempelajarinya sering terjadi kesalahan dalam penulisan klasifikasi (taksonomi) dan tata nama ilmiah pada tumbuhan.

Dalam memanfaatkan kemajuan teknologi saat ini dan juga dalam memudahkan serta mempelajari taksonomi tumbuhan kingdom plantae maka perlu dibuatkan aplikasi tentang taksonomi tumbuhan berbasis android. Dibuatkan berbasis android karena banyak pengguna android saat ini sehingga akan mudah digunakan masyarakat dan lebih praktis.

Untuk memudahkan pengguna dalam mencari data pada aplikasi taksonomi tumbuhan, pada aplikasi perlu adanya suatu proses pencarian. Pencarian yang diterapkan pada aplikasi taksonomi tumbuhan yaitu menggunakan cara string matching.

String Maching merupakan salah satu jenis cara yang bertujuan untuk mencocokan karakter dimana cara ini bekerja untuk mencocokan suatu karakter yang disebut pattern dalam suatu kumpulan teks. Salah satu jenis string matching adalah algoritma Horspool. Algoritma Horspool merupakan turunan dari algoritma Boyer-Moore dan mudah dalam implementasinya. Algoritma Horspool hanya menggunakan perpindahan bad character yang terjadi pada Boyer Moore.

Kata Kunci : Taksonomi,Plantae, Android, String Matching, Horspool

Taxonomy itself has many branches. One of them is the taxonomy of plants (Plantae), plant taxonomy more studies aspects of plant samples and groupings. In understanding the classification (taxonomy) and scientific nomenclature, the tools commonly used are textbooks or classification tables (taxonomy) and scientific nomenclature so that they are less practical. Many people, students and students find it difficult to memorize because Latin and classification (taxonomy) consist of many objects. The types and species of plants are very large, so that in studying them, mistakes often occur in writing classifications (taxonomy) and scientific nomenclature in plants.

In utilizing current technological advances and also in facilitating and studying the taxonomy of kingdom plantae plants, it is necessary to make an application about the taxonomy of androidbased plants. Made based on Android because there are many Android users now so that it will be easy to use and more practical for the community.

To facilitate users in searching for data on plant taxonomy applications, the application needs a search process. Searches that are applied to plant taxonomy applications are using string matching methods.

String Maching is one type of method that aims to match characters where this method works to match a character called a pattern in a collection of texts. One type of string matching is the Horspool algorithm. Horspool algorithm is a derivative of the Boyer-Moore algorithm and easy to implement. Horspool's algorithm only uses the displacement of bad character that happened to Boyer Moore. 
Keywords: Taxonomy, Plantae, Android, String Matching, Horspool,

\section{PENDAHULUAN}

Ilmu Biologi tergolong dalam ilmu sains yang memiliki karakteristik khusus yang berbeda dengan ilmu lainnya dalam hal objek, persoalan, dan metodenya. Berdasarkan struktur keilmuan menurut BSCS (Biological Science Curriculum Study), Biologi mempunyai obyek berupa Kingdom (kerajaan): Animalia (dunia hewan), Plantae (dunia tumbuhan), dan Protista. Objek yang berjumlah ribuan jenis menjadi kesulitan tersendiri untuk dipelajari. Salah satu cara mempermudah dalam mempelajarinya adalah pengelompokan atau pengklasifikasian makhluk hidup disebut Taksonomi.

Ilmu taksonomi sendiri memiliki banyak sekali cabangnya. Salah satunya adalah taksonomi tumbuhan (Plantae), Taksonomi tumbuhan lebih banyak mempelajari aspek sampel-sampel tumbuhan dan pengelompokan. Dalam memahami klasifikasi (taksonomi) dan tata nama ilmiah, alat bantu yang umum digunakan adalah buku pelajaran atau tabel klasifikasi (taksonomi) dan tata nama ilmiah sehingga kurang praktis. Banyak masyarakat, siswa maupun mahasiswa sulit untuk menghafal karena berbahasa latin dan klasifikasi (taksonomi) terdiri dari banyak objek. Jenis dan spesies tumbuhan sangat banyak, sehingga dalam mempelajarinya sering terjadi kesalahan dalam penulisan klasifikasi (taksonomi) dan tata nama ilmiah pada tumbuhan.

Dalam memanfaatkan kemajuan teknologi saat ini dan juga dalam memudahkan serta mempelajari taksonomi tumbuhan kingdom plantae maka perlu dibuatkan aplikasi tentang taksonomi tumbuhan berbasis android. Dibuatkan berbasis android karena banyak pengguna android saat ini sehingga akan mudah digunakan masyarakat dan lebih praktis.

Untuk memudahkan pengguna dalam mencari data pada aplikasi taksonomi tumbuhan, pada aplikasi perlu adanya suatu proses pencarian. Pencarian yang diterapkan pada aplikasi taksonomi tumbuhan yaitu menggunakan cara string matching.

String Maching merupakan salah satu jenis cara yang bertujuan untuk mencocokan karakter dimana cara ini bekerja untuk mencocokan suatu karakter yang disebut pattern dalam suatu kumpulan teks. Salah satu jenis string matching adalah algoritma Horspool. Algoritma Horspool merupakan turunan dari algoritma BoyerMoore dan mudah dalam implementasinya. Algoritma Horspool hanya menggunakan perpindahan bad character yang terjadi pada Boyer Moore. Algoritma ini lebih efisien digunakan ketika ditemukan panjang pattern yang kecil (Sheik, S.S. et al.2004).

Dari uraian di atas, maka penulis memilih judul yaitu "IMPLEMENTASI ALGORITMA HORSPOOL PADA APLIKASI TAKSONOMI BERBASIS ANDROID".

Dari latarbelakang diatas, maka dapat diketahui rumusan masalah sebagai berikut :

1. Bagaimana membangun sebuah aplikasi taksonomi tumbuhan pada sistem operasi android?

2. Bagaimana menerapkan algoritma Horspool dalam proses pencarian taksonomi tumbuhan?.

Batasan masalah dalam penelitian ini adalah:

1. Algoritma yang digunakan adalah Horspool, yang terdiri dari fase bad character shift dan proses matching.

2. Data yang dimasukan hanya taksonomi tumbuhan pada kingdom plantae.

3. Data dicari berdasarkan nama umum dan nama latin.

4. Data bersumber dari buku berjudul Taksonomi Tumbuhan (Spermatophyta) karangan Gembong Tjitrosoepomo dan website plantamor.com dengan jumlah data yang dimasukan berjumlah 150 data.

5. Aplikasi dibuat berbasis client server dengan database MySql.

6. Aplikasi client dibuat berbasis android dengan bahasa pemrograman java sedangkan aplikasi server dibuat menggunakan bahasa pemrograman php.

\section{METODELOGI PENELITIAN}

\subsection{Metode Pengembangan Sistem}

Metodologi pengembangan perangkat lunak yang digunakan penulis yaitu Metode Rational Unifield Process (RUP) dengan alasan Metode pengembangan ini sangat cocok untuk pemrograman berorientasi objek. Rational Unified 
Process (RUP) merupakan proses pengembangan perangkat lunak yang dilakukan secara iteratif (berulang) dan inkremental (bertahap dengan progres menaik). Iteratif bisa dilakukan dalam setiap tahap atau iteratif tahap pada proses pengembangan perangkat lunak untuk menghasilkan perbaikan fungsi yang inkremental (bertambah naik) dimana setiap iterasi akan memperbaiki iterasi berikutnya. Salah satu Unifield Process yang dikenal adalah RUP (Rational Unifield Process) (AS Rosa dan M. Shalahuddin, 2013.124).:

RUP memiliki 4 tahap atau fase yang dapat dilakukan pula secara iterative, berikut adalah penjelasan untuk setiap fase RUP :

\section{Inception}

Tahap ini lebih pada memodelkan proses bisnis yang dibutuhkan (business modeling) dan mendefinisikan kebutuhan akan sistem yang akan dibuat (requirements).

\section{Elaboraion}

Tahap ini lebih pada analisis dan desain sistem serta implementasi sistem yang fokus pada purwarupa sistem (prototype).

\section{Construction}

Tahapan ini lebih pada implementasi dan pengujian sistem yang fokus pada implementasi perangkat lunak pada kode program.

\section{Transition}

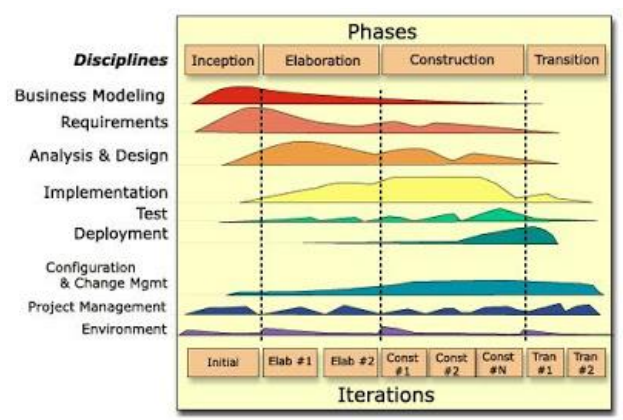

Gambar 1. Gambar Fase RUP

\subsection{Teknik Pengumpulan Data}

Teknik pengumpulan data yang dilakukan oleh penulis yaitu:

1. Studi Pustaka

Mempelajari literatur tentang teori dasar yang mendukung penelitian ini yang bersumber dari buku, internet atau jurnal yang ada hubungannya dengan taksonomi tumbuhan, string matching dan algoritma Horspool.

2. Analisis dan Pengumpulan Data Menganalisa apa saja yang dibutuhkan untuk membangun aplikasi ini, serta mengumpulkan data mengenai taksonomi tumbuhan pada kingdom plantae yang akan digunakan dalam aplikasi ini.

\section{HASIL DAN PEMBAHASAN \\ 3.1 Analisis Sistem yang Diusulkan}

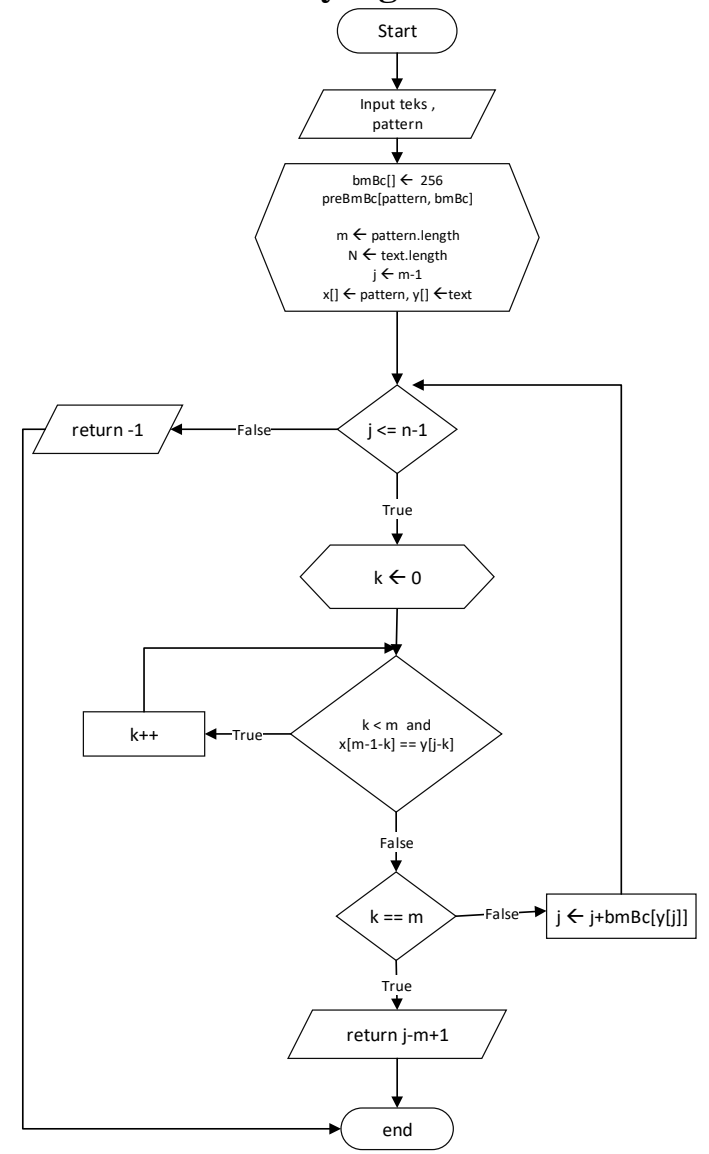

Gambar 2. Flowchart Algoritma Horspool 3.2 Perancangan Use Case Diagram

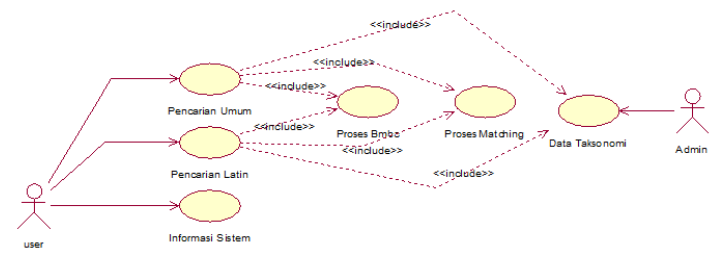

Gambar 3. Use case diagram sistem Pada gambar 3 use case diagram akan di deskripsikan sebagai berikut :

\subsection{Activity Diagram}


Diagram activity akan menampilkan aliran kerja atau aktivitas dari sebuah sistem yang ada pada aplikasi. Di mana aktivitas ini akan menggambarkan aktivitas sistem dan bukan yang di lakukan oleh aktor terhadap aplikasi, jadi activity diagram ini akan menampilkan aktivitas-aktivitas yang dilakukan oleh system.

\section{a. Activity Diagram pencarian umum}

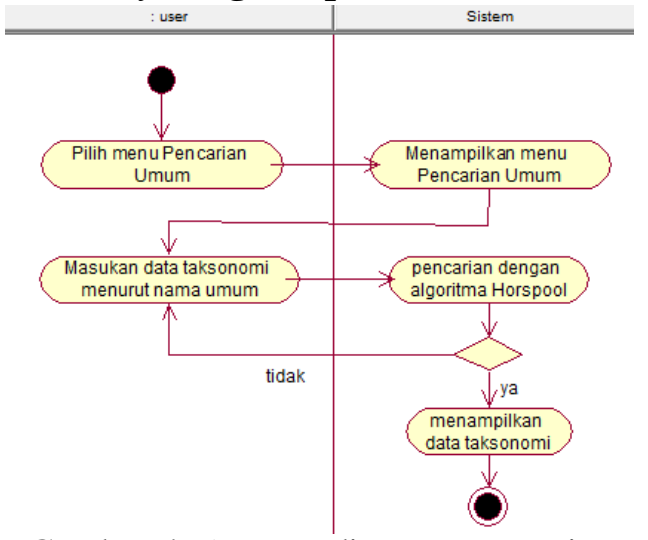

Gambar 4. Activity diagram pencarian umum

\section{b. Activity Diagram pencarian latin}

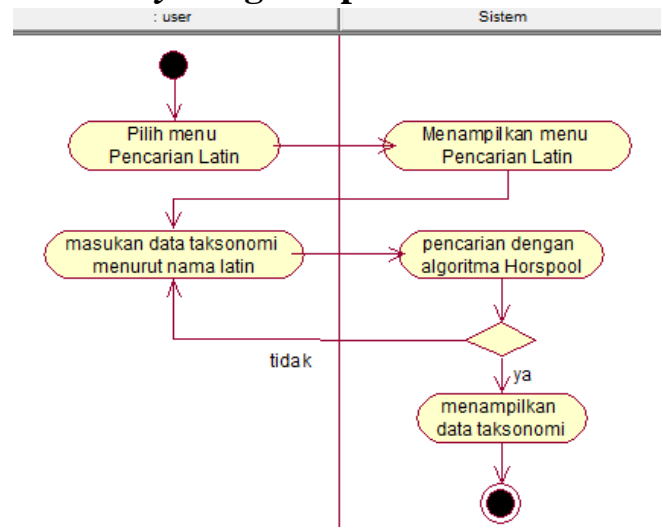

Gambar 5. Activity diagram pencarian latin c. Activity Diagram data taks onomi

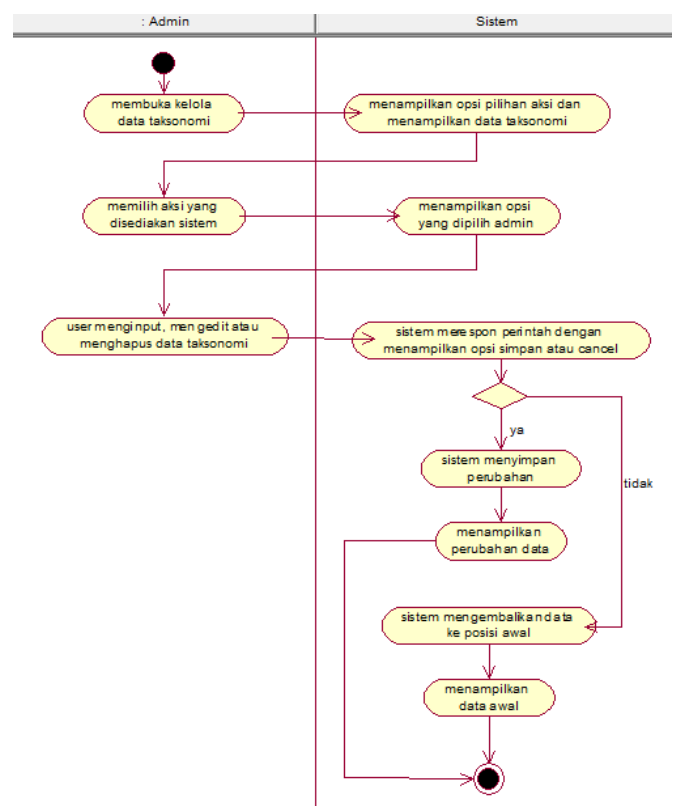

Gambar 6. Activity diagram data taksonomi

\subsection{Class Diagram}

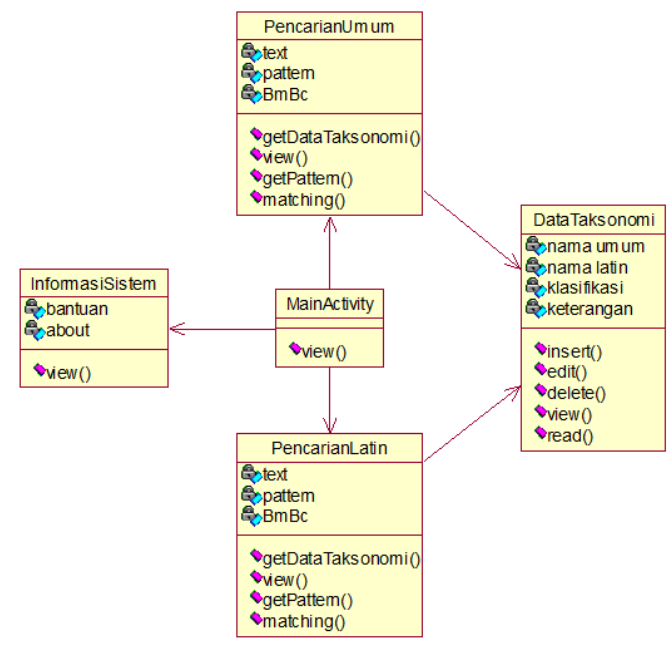

Gambar 7. Class Diagram

\subsection{Sequence Diagram}

a. Sequence Diagram pencarian umum 
JURNAL BUFFER INFORMATIKA

Volume 4 Nomor 2, Oktober 2018

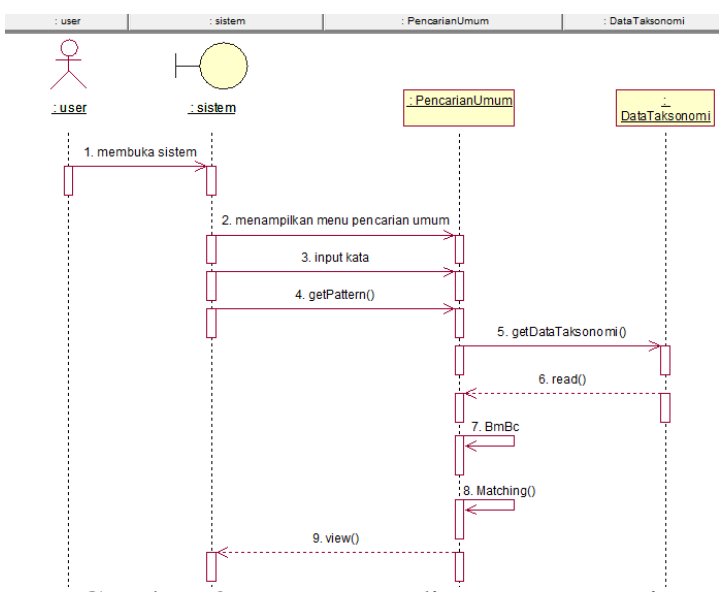

Gambar 8. sequence diagram pencarian umum

\section{b. Sequence Diagram pencarian latin}

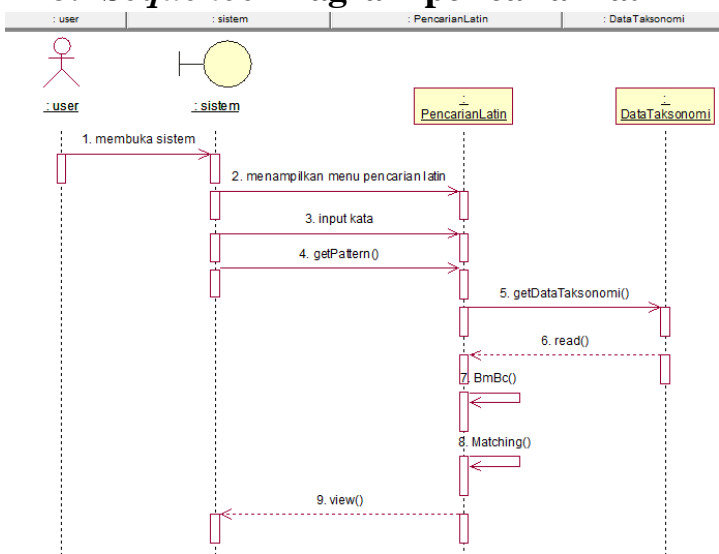

Gambar 9. Sequence diagram pencarian latin c. Sequence Diagram taksonomi

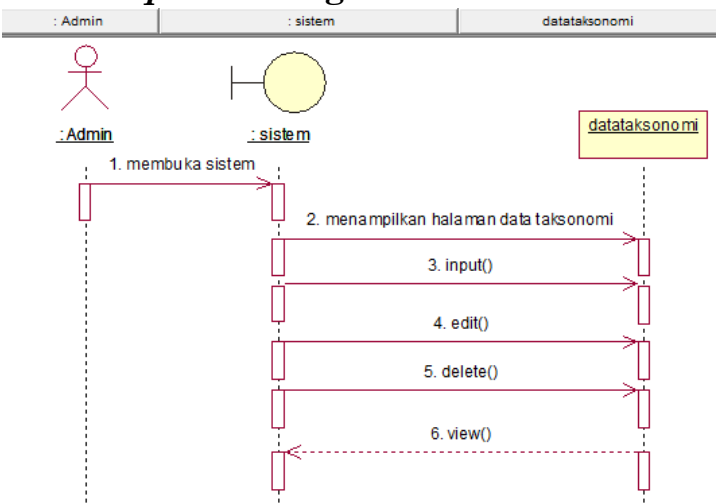

Gambar 10. Sequence taksonomi

\subsection{Construction}

Setelah mengalami sederetan proses iterasi, pada tahapan Construction ini sudah dapat menghasilkan suatu aplikasi. Hasil dari aplikasi yang sudah dirancang dapat dilihat pada tampilan Gambar berikut :

1. Halaman Utama Aplikasi
p-ISSN : 2527-4856, e-ISSN : 2614-5413

https ://journal.uniku.ac.id/index.php/buffer

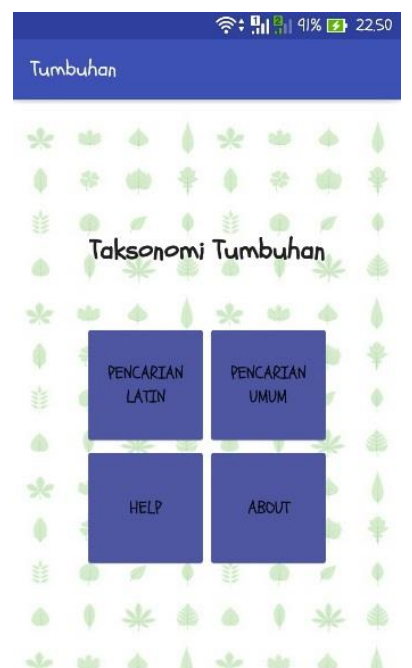

Gambar 11. Halaman Utama Aplikasi 2. Halaman utama

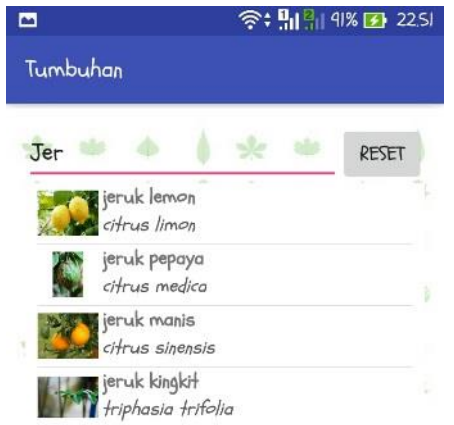

Gambar 12. Tampilan halaman utama.

3. Halaman Menu pencarian

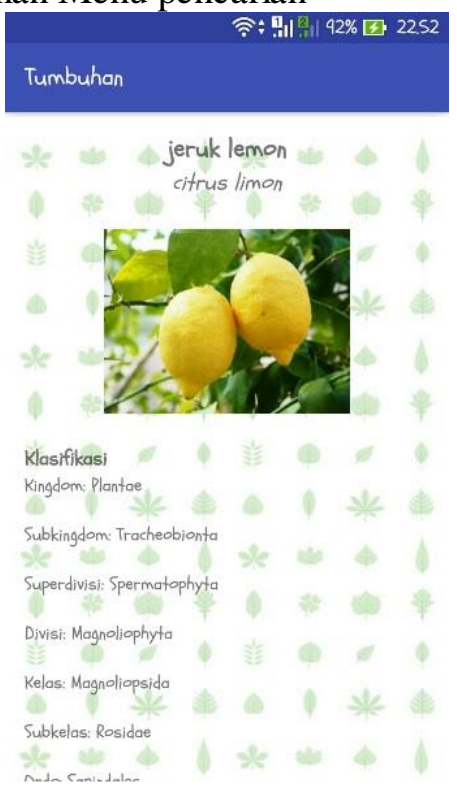

Gambar 13. Halaman pencarian 3.7 Pengujian Perangkat Lunak 
Pengujian black box adalah proses pengujian aspek fundamental aplikasi tanpa memperhatikan struktur logika internal perangkat lunak. Proses pengujian ini dilakukan untuk mengetahui apakah aplikasi perangkat lunak dapat berjalan dan berfungsi dengan benar.

\section{Pengujian Black Box}

Tabel 1.Hasil Pengujian Black Box

\begin{tabular}{|c|c|c|c|c|}
\hline No & $\begin{array}{c}\text { Fungsi } \\
\text { yang } \\
\text { Diuji }\end{array}$ & Skenario & $\begin{array}{l}\text { Hasil yang } \\
\text { diharapkan }\end{array}$ & $\begin{array}{c}\text { Hasil } \\
\text { uji }\end{array}$ \\
\hline 1 & $\begin{array}{l}\text { Tampilan } \\
\text { awal }\end{array}$ & $\begin{array}{l}\text { Membuka } \\
\text { aplikasi }\end{array}$ & $\begin{array}{l}\text { Muncul } \\
\text { tampilan awal } \\
\text { aplikasi } \\
\text { beserta } \\
\text { fiturnya }\end{array}$ & Valid \\
\hline 2 & $\begin{array}{l}\text { Pencarian } \\
\text { menurut } \\
\text { nama } \\
\text { umum }\end{array}$ & $\begin{array}{l}\text { Memilih } \\
\text { menu } \\
\text { Pencarian } \\
\text { Umum } \\
\text { dan } \\
\text { menginput } \\
\text { kan nama } \\
\text { umum } \\
\text { tumbuhan }\end{array}$ & $\begin{array}{l}\text { Menampilkan } \\
\text { list data } \\
\text { tumbuhan } \\
\text { berdasarkan } \\
\text { nama umum } \\
\text { yang di input }\end{array}$ & Valid \\
\hline 3 & $\begin{array}{l}\text { Pencarian } \\
\text { menurut } \\
\text { nama } \\
\text { latin }\end{array}$ & $\begin{array}{l}\text { Memilih } \\
\text { menu } \\
\text { Pencarian } \\
\text { Umum } \\
\text { dan } \\
\text { menginput } \\
\text { kan nama } \\
\text { umum } \\
\text { tumbuhan }\end{array}$ & $\begin{array}{l}\text { Menampilkan } \\
\text { list data } \\
\text { tumbuhan } \\
\text { berdasarkan } \\
\text { nama latin } \\
\text { y ang di input }\end{array}$ & Valid \\
\hline 4 & $\begin{array}{l}\text { Detail } \\
\text { data } \\
\text { taksonomi }\end{array}$ & $\begin{array}{l}\text { Memilih } \\
\text { data } \\
\text { tumbuhan } \\
\text { pada list }\end{array}$ & $\begin{array}{l}\text { Muncul } \\
\text { tampilan } \\
\text { tentang detail } \\
\text { dari data } \\
\text { taksonomi } \\
\text { yang di pilih }\end{array}$ & Valid \\
\hline 5 & $\begin{array}{l}\text { Buka } \\
\text { menu } \\
\text { Help }\end{array}$ & $\begin{array}{l}\text { Memilih } \\
\text { menu } \\
\text { Help }\end{array}$ & $\begin{array}{l}\text { Menampilkan } \\
\text { bantuan dan } \\
\text { petunjuk } \\
\text { penggunaan } \\
\text { aplikasi }\end{array}$ & valid \\
\hline 6 & $\begin{array}{l}\text { Buka } \\
\text { menu } \\
\text { About }\end{array}$ & $\begin{array}{l}\text { Memilih } \\
\text { menu } \\
\text { About }\end{array}$ & $\begin{array}{l}\text { Menampilkan } \\
\text { tentang } \\
\text { pembuat } \\
\text { aplikasi }\end{array}$ & valid \\
\hline 7 & $\begin{array}{l}\text { Buka } \\
\text { menu } \\
\text { login } \\
\text { admin }\end{array}$ & $\begin{array}{l}\text { Membuka } \\
\text { halaman } \\
\text { login } \\
\text { admin }\end{array}$ & $\begin{array}{l}\text { Muncul } \\
\text { tampilan input } \\
\text { username dan } \\
\text { password }\end{array}$ & Valid \\
\hline 8 & $\begin{array}{l}\text { Tampilan } \\
\text { halaman } \\
\text { admin }\end{array}$ & $\begin{array}{l}\text { Menginpu } \\
\text { tkan } \\
\text { username } \\
\text { dan } \\
\text { password } \\
\text { dengan }\end{array}$ & $\begin{array}{l}\text { Muncul } \\
\text { tampilan } \\
\text { halaman } \\
\text { administator, } \\
\text { dimana } \\
\text { didalamnya }\end{array}$ & Valid \\
\hline
\end{tabular}

\begin{tabular}{|c|c|c|c|c|}
\hline & & benar & $\begin{array}{l}\text { dapat input, } \\
\text { edit, delete, } \\
\text { cari dan } \\
\text { melihat data } \\
\text { taksonomi } \\
\text { y ang ada }\end{array}$ & \\
\hline 9 & Input data & $\begin{array}{l}\text { Memasuk } \\
\text { an data } \\
\text { taksonomi } \\
\text { dari mulai } \\
\text { bahasa } \\
\text { latin, } \\
\text { bahasa } \\
\text { umum, } \\
\text { klasifikasi, } \\
\text { detail dan } \\
\text { foto }\end{array}$ & $\begin{array}{l}\text { Data berhasil } \\
\text { di simpan ke } \\
\text { dalam } \\
\text { database dan } \\
\text { di tampilkan } \\
\text { pada aplikasi } \\
\text { android }\end{array}$ & Valid \\
\hline 10 & Edit data & $\begin{array}{l}\text { Memilih } \\
\text { aksi edit } \\
\text { pada } \\
\text { kolom } \\
\text { Action }\end{array}$ & $\begin{array}{l}\text { Muncul } \\
\text { tampilan edit } \\
\text { beserta } \\
\text { dengan data } \\
\text { taksonomi } \\
\text { y ang akan di } \\
\text { edit, apabila } \\
\text { melakukan } \\
\text { perubahan } \\
\text { data maka } \\
\text { data baru } \\
\text { tersimpan di } \\
\text { database }\end{array}$ & Valid \\
\hline 11 & $\begin{array}{l}\text { Delete } \\
\text { data }\end{array}$ & $\begin{array}{l}\text { Memilih } \\
\text { aksi } \\
\text { remove } \\
\text { pada } \\
\text { kolom } \\
\text { Action }\end{array}$ & $\begin{array}{l}\text { Akan muncul } \\
\text { pemberitahuan } \\
\text { bahwa apakah } \\
\text { yakin data } \\
\text { akan di hapus, } \\
\text { dan apabila } \\
\text { iya maka data } \\
\text { terhapus }\end{array}$ & Valid \\
\hline 12 & $\begin{array}{l}\text { Cari data } \\
\text { taksonomi } \\
\text { pada } \\
\text { halaman } \\
\text { admin }\end{array}$ & $\begin{array}{l}\text { Menginpu } \\
\text { tkan nama } \\
\text { umum } \\
\text { ataupun } \\
\text { nama latin } \\
\text { pada } \\
\text { kolom } \\
\text { search }\end{array}$ & $\begin{array}{l}\text { Muncul data } \\
\text { y ang di } \\
\text { inputkan } \\
\text { admin }\end{array}$ & Valid \\
\hline 13 & $\begin{array}{l}\text { Buka } \\
\text { menu } \\
\text { tentang } \\
\text { pada } \\
\text { halaman } \\
\text { admin }\end{array}$ & $\begin{array}{l}\text { Memilih } \\
\text { menu } \\
\text { tentang } \\
\text { pada } \\
\text { halaman } \\
\text { admin }\end{array}$ & $\begin{array}{l}\text { Muncul } \\
\text { tampilan } \\
\text { tentang } \\
\text { aplikasi }\end{array}$ & Valid \\
\hline 14 & Logout & $\begin{array}{l}\text { Memilih } \\
\text { menu } \\
\text { logout }\end{array}$ & $\begin{array}{l}\text { Keluar dari } \\
\text { aplikasi }\end{array}$ & Valid \\
\hline
\end{tabular}

\section{Pengujian White Box}

Pengujian White Box Testing dapat dilakukan sebagai berikut :

a. $\mathrm{V}(\mathrm{G})=\mathrm{E}-\mathrm{N}+2$ hasilnya sama dengan $\mathrm{V}(\mathrm{G})=\mathrm{P}+1$ 
b. Flowgraph mempunyai region yang sama dengan jumlah V(G)maka sistem dikatakan sudah terbukti efektif dan efisien.

\section{Flow Graph Nation}

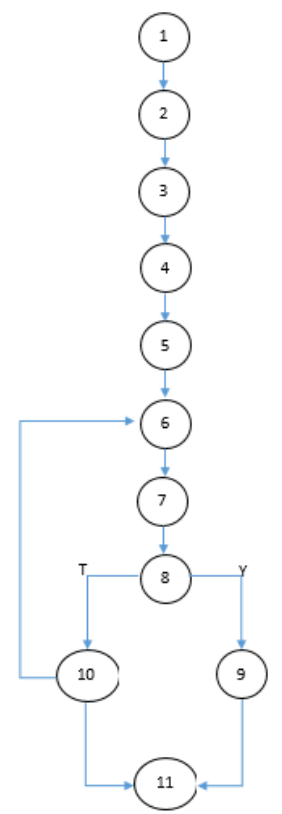

Gambar 14. Flow Graph Nation

Cyclomatic Complexity dari Flow

Graph diatas dapat diperoleh dengan cara menghitung daerah yang dapat dibentuk oleh graph yaitu sebanyak 3. Atau bisa dihitung dengan menggunakan rumus :

$\mathrm{V}(\mathrm{G})=\mathrm{E}-\mathrm{N}+2$.

Diketahui :

$\mathrm{E}=($ Jumlah edge pada flow graph $)=12$

$\mathrm{N}=($ Jumlah node pada flow graph $)=11$

Maka, $\mathrm{V}(\mathrm{G}) \quad=\mathrm{E}-\mathrm{N}+2$

$$
\begin{aligned}
& =12-11+2 \\
& =3
\end{aligned}
$$

Jadi hasil perhitungan Cyclomatic Complexity pada gambar 4.11 adalah 3 . Berdasarkan Cyclomatic Complexity tersebut, maka terdapat 3 path atau jalur yang terdiri dari :

Path $1: 1-2-3-4-5-6-7-8-9-11$

Path $2: 1-2-3-4-5-6-7-8-10-11$ Path $3: 1-2-3-4-5-10-6-7-8-9-$ 11

\section{KESIMPULAN}

1. Aplikasi taksonomi berbasis android dapat dibuat sehingga nantinya akan memudahkan masyarakat, siswa, maupun mahasiswa yang ingin mencari data
p-ISSN : 2527-4856, e-ISSN : 2614-5413

https ://journal.uniku.ac.id/index.php/buffer

tentang taksonomi tumbuhan kingdom plantae.

2. Algoritma Horspool dapat diimplementasikan kedalam aplikasi taksonomi berbasis android dimana algoritma Horspool diterapkan pada kolom pencarian latin maupun pencarian umum.

3. Pengelolaan data taksonomi dapat dilakukan, dengan fungsi tambah untuk menambah data taksonomi, edit untuk merubah data taksonomi, lihat untuk melihat data yang ada dan fungsi delete untuk menghapus data taksonomi.

\section{Saran}

1. Untuk pengembangan selanjutnya, diharapkan agar dapat menangani pergeseran pattern dari arah spesifik yang ditentukan oleh algoritma (in a specific order) untuk proses pencarian yang lebih efisien.

2. Diharapkan aplikasi ini menyediakan menu pilihan algoritma berbagai pencocokan string seperti Boyer Moore, Knuth Morris Pratt, Reverse Colussi sehingga memberi pengetahuan lebih tentang algoritma pencocokan string.

3. Dibuatkan juga untuk platform yang lain, seperti Blackberry OS, iOS, ataupun yang lainnya.

\section{DAFTAR PUSTAKA}

A.S Rosa, Shalahuddin M.(2013).Rekayasa Perangkat Lunak Terstruktur dan Berorientasi Objek.Bandung.Penerbit: Informatika

Agustiani, Ita. 2016. Implementasi Algoritma Horspool untuk Pencarian Data Skripsi Berbasis Mobile (Studi Kasus : Teknik Informatika Universitas Kuningan). Program Studi Teknik Informatika, Universitas Kuningan.

Amirudin, Ahmad. 2015. Pengembangan Aplikasi Sistem Pembelajaran Klasifikasi (Taksonomi) dan Tata Nama Ilmiah (Binomial Nomenklatur) Pada Kingdom Plantae (Tumbuhan) Berbasis Android. Universitas Lampung

Cato Chandra,S.Kom dan Ir. Teddy Marcus Zakaria,M.T.2008.Be Smart Be. 
Profesional With Microsoft Office 2007.Informatika.Bandung

Charras C, Raymond., dan T.Lecroq (2009), Handbook of Exact String Matching Algoritm.

URL: http $/ /$ ebookee.org/Handbook-of-ExactString-MatchingAlgorithms_892540.html.

Cormen, T.H., Leiserson, C.E., Rivest, R.L. \& Stein, C. 1994. Introduction to Algorithms. McGraw-Hill Book Company: North America.

Effendi, D., Hartono, T. \& Kurnaedi, A. 2013. Penerapan string matching menggunakan algoritma Boyer-Moore pada translator bahasa Pascal ke C. Majalah Ilmiah Unikom Vol. 11, No. 2: 262-271.

Febrian, Jack. 2007. Kamus Komputer dan Teknologi Informasi. Penerbit Informatika. Bandung

Hakim, Lukmanul.(2008). RaRahasia Inti Master PHP dan MySQLi(improved). Yogyakarta : Lokomedia

Hendrayudi. 2009. VB 2008 Untuk Berbagai Keperluan Programming. Jakarta. PT Elex Media Komputindo

Horspool, R.N. 1980. Practical fast searching in strings. Journal Software Practice and ExperienceVol. 10: 501-506.

Kadir, Abdul. 2010. Tuntunan Praktis: Belajar Database Menggunakan MySQL. Yogyakarta : Andi.

Knuth D.E., Morris (Jr) J.H. \& Pratt V.R. 1977. Fast pattern matching in strings. SIAM Journal on ComputingVol. 6, No.1: 323-350.

Kustiyahningsih, Y. dan Anamisa, D. R. 2011. Pemrograman Basis Data Berbasis Web Menggunakan PHP\& MySQL. Edisi Pertama. Yogyakarta: Graha Ilmu.

Martinus, Surawan dan Hartono, R. Sapto. 2008. KAMUS NOMENKLATUR: Mudah Mencari Padanan Kata LatinIndonesia \& Indonesia Latin. Andi Offset: Yogyakarta. $178 \mathrm{hlm}$.

Nasution, Ade Mutiara Kartika. 2016. Implementasi Algoritma Horspool Dalam Pembuatan Kamus Istilah Psikologi Pada Platform Android. Program Studi Ilmu Komputer, Universitas Sumatra Utara.
Nugroho, Adi (2009). Rational Rose Untuk Pemodelan Berorientasi Objek. Bandung.Penerbit : Informatika.

Pramana, H, W. (2006). Aplikasi Inventory Berbasis Access. Jakarta : Elex Media Komputindo

Pressman, Roger S.(2010) Rekayasa Perangkat Lunak. Yogyakarta: Andi.

Safaat H, Nazarudin. 2012. (Edisi Revisi) Pemograman Aplikasi Mobile Smartphone dan Tablet PC Berbasis Android. Informatika:Bandung.

Sibero, Alexander F.K. 2011. Kitab Suci Web Programming. Yogyakarta: Mediakom.

Simarmata, Janner. 2010. Rekayasa Perangkat Lunak. Yogyakarta: Andi.

Singh, R. \& Verma, H.N. 2011. A fast string matching algorithm. International Journal of Computer Technology and Applications Vol. 2, No. 6: 18771883.

Sismoro Heri. 2005. Pengantar Logika Informatika, Algoritma, dan Pemrograman Komputer. Andi. Yogyakarta.

Soepomo. 2010. Morfologi Tumbuhan. Yogyakarta: Pt. Gajah Muda University Press.

Sutarman. 2009. Pengantar Teknologi Informasi. Yogyakarta : Bumi Aksara

Supono, dan Virdiandry Putratama. 2016. Pemrograman Web dengan Menggunakan PHP dan Framework Codeigniter. Yogyakarta: deepublish.

Suryana, Taryana (2007) Metode RUP Rational Unified Process. Metode RUP Rational Unified Process. Universitas Komputer Indonesia 